\title{
Coastal Community Resistance in Preventing Environmental Damage in Galesong Beach of Takalar, Indonesia
}

\author{
Rusdin Nawi, Al-Muhajir Haris ${ }^{1}$, Andi Rosdianti Razak ${ }^{2}$ \\ \{almuhajirharis@gmail.com²\} \\ Universitas Pancasakti Makassar \\ Universitas MuhammadiyahMakassar ${ }^{2}$
}

\begin{abstract}
Coastal community resistance is a personal or group ability to take an action that shows a form of rejection to the form of the problem. Failure of the company's responsibility in its activities can cause harm to the community and the environment. This writing places a coastal community's resistance on the company about environmental damage. This research method uses qualitative descriptive. The focus of this research is on the Galesong coastal community and as many as 15 informants between the government, companies, community leaders and the community. From the results in general shows that the resistance of the Galesong coastal community continues to occur continuously to the company, it was triggered by the lack of control and supervision carried out by the government on the company, causing a loss to the community and the environment.
\end{abstract}

Keywords: Coastal Community, Environmental Damage, Resistance

\section{Introduction}

Indonesia is a maritime country that has the widest sea area in the world, all forms of marine organism's wealth is very abundant with it, coastal fishermen communities certainly provide good benefits for their economic sectors because the amount of Indonesia's marine wealth is so large and abundant. However, this is only a story because the amount of environmental damage to marine ecosystems is caused by companies that are not responsible for damage to it. The cause of damage to other ecosystems is influenced by various human activities themselves [1].

The biggest contributors to environmental damage on this earth are businesses (companies) due to various kinds of problems they have done such as waste, pollution and they leave severe damage to the environment that they have previously managed [2].

Seeing the damage that occurs continuously, especially in the Indonesian marine ecosystem, it invites damage to coral reefs, marine organisms, especially in the number of fish populations. Apart from that sea damage caused by sand mining located on the coast tends to have a very large impact on coastal communities, this has a bad impact on the economic sector of the local community, which is very urgent is the occurrence of abrasion in coastal areas.

Entering the mid-twentieth century, the community resistance movement opposed environmental damage [3]. This movement wants a revolutionary change of relations between humans and the universe by reviewing the concepts of metaphysics, cosmology and 
environmental ethics towards nature. Modern human civilization is now increasingly looking to master exploitation. Environmental damage, pollution and damage to the earth are a few examples that occur at this time. This nation's historical experience shows that social movements in Indonesia are a movement with a long series of episodes. The tragedy of failure after failure becomes a part that is never separated and always follows the struggle to achieve the goal of the movement [4].

Social movements as resistance politics that occur when ordinary people who join more influential groups of people mobilize forces to fight the elites, the authorities and other opponents. The strong ethos of the movement circulated among the oppressed about the struggle between the Queen of Justice and the Ruler of injustice that ended in victory was nothing more than a romantic trap [5].

The main activities of the government in dealing with the problem of pollution and environmental damage are already contained in the Law. Environmental damage described in law number 32 of 2009 concerning environmental management and protection states that environmental damage is a direct or indirect change in physical properties. Apart from the law, there is also the regulation of the Governor of South Sulawesi Province Number 3 of 2014 concerning Protection and Management of the Environment, that a good and healthy Environment is one of the Human Rights possessed by every Man as mandated in the Constitution of the Republic of Indonesia in 1945, it was necessary to maintain its quality so that it could still support sustainable development.

In this case, in a Takalar regency, precisely at the beach of Galesong, there is a case of environmental damage. As a result of environmental damage, the people of the coastal area of Galesong are fighting against the sand mining company. The firm sand mining activities started in 2013 to 2018 today.

Environmental damage that occurs in the region triggers all existing problems. In this problem, giving influence to the economic sector of the coastal community becomes more reduced due to the lack of supply of fish caught by fishermen in the coastal area of Galesong.

\section{Methodology}

This research uses descriptive qualitative research. The data used in this study was obtained from the head of the PPLH section of Takalar District, WALHI, the Government of the Sub-District Head, Non-Governmental Organizations (LSM), and coastal communities. Data collection techniques used are observation, documentation, and interviews.

\section{Result and Discussion}

One of the things that has increased the economy in an industrial sector certainly has to sacrifice the environment, this concept is a concept that is understood as part of the government and supported by businesses. From the understanding of the concept, business actors continuously use the land for excessive exploitation. The current environmental damage cannot be limited anymore to see the number of land exploitation actors that are excessively occurring in our environment, both in our own country and abroad. The damage to the environment has made environmental organizations, NGOs and the public fight against issues concerning environmental damage, the government is considered to have failed in resolving this problem. They consider the government to work with corporations in carrying out the business objectives they want to achieve. 
Environmental damage that occurs at this time such as sand mining which continues to occur on the coast of Galesong is a frightening specter for coastal communities, it is a challenge faced by the community and local government. The sand mining activities that are continuously carried out by the company have a terrible impact on all levels. Various paths taken by coastal communities to solve this problem began with the coastal community's resistance to the community and dialogue with NGOs, WALHI and the local government, however, there were no settlement points resolved.

The influence of the economy is in the spotlight for the Galesong coastal community, based on sources from local NGOs that there are four companies that conduct sand mining including PT. Minertatama, PT. Gasing Sulawesi, PT. Yasmin Bumi Asri and PT. Lautan Phinisi Resources from these four companies is conducting sand mining activities along the Galesong coast, according to the company they have obtained permission from the relevant government. Broadly speaking, the government gives business licenses to business actors, but the most important thing that must be considered is how the government collaborates on stakeholder to supervise the company's activities to support environmental safety in a sustainable manner.

The sustainable development in question is to preserve the environment and maintain it in accordance with the values of ethos in the environment. This is a form of environmental conservation carried out in various parts of the country, how they are able to respect ecosystems in the environment. Environmental safety is needed for all living things because basically all living things depend on the conditions of the environment.

\section{Conclusion}

The resistance of the Galesong coastal community to the sand mining company continues to this day, various methods have been carried out but have not been successful. The various stackholders that they met to discuss and resolve these issues had no bright spots and there was no agreement between the two parties. In this case, due to the company's mining activities that occurred on the Galesong coast, the environmental conditions were damaged, and gave a negative influence on the economic sector of the coastal community.

The solution to this problem is an effort that must be resolved, between various parties of the government, as well as various interest groups in discussing the study of this problem. In addition, the role of the government is needed to review the problems that arise in the conditions in the field, both in terms of licensing and supervision, so that this problem can be resolved and no form of loss must occur. Understanding the balance and sustainable environmental safety that needs to be applied in this problem.

\section{References}

[1] P. Y. T. Tiana, "Identifikasi Bentuk-Bentuk Investasi Pengelolaan Lingkungan Oleh Sektor Industri Studi Kasus: PT Coca Cola Bottling Indonesia Divisi Jawa Tengah, PT. Leo Agung Raya, PT Djarum Kudus, dan Sentra Industri Tahu Jomblang," Universitas Diponegoro, 2006.

[2] I. Dincer and M. A. Rosen, "Energy, environment and sustainable development," Appl. Energy, vol. 64, no. 1-4, pp. 427-440, 1999.

[3] W. Bello, "The environmental movement in the global South: The pivotal agent in the fight against global warming," Focus Glob. South, vol. 12, 2007. 
[4] A. W. Situmorang, Gerakan Sosial Teori dan Praktek. Yogyakarta: Pustaka Pelajar, 2013.

[5] S. Murata, The Tao of Islam. Bandung: Mizan, 1996. 